\title{
Sloshing Simulation of Three Types Tank Ship on Pitching and Heaving Motion
}

\author{
Edi Jadmiko ${ }^{1}$ Yoga Adhi Pratama ${ }^{2}$
}

\begin{abstract}
- as an important part of a ship, tanker / cargo hold specifically designed to distribute the load to be maintained safely. In a related IMO classification of LNG carrier, there are a wide variety of types of LNG tanks on ships. Are generally divided into two types, namely tank (Independent Self Supporting Tank) and (Non Self Supporting Tanks). The tank-type variation will affect the characteristics of fluid motion that is inside the tank. Need for simulation of sloshing and analysis of the structure of the tank due to the force created by the load when the heaving and pitching. Sloshing the effect of the free movement of the fluid in the tank with the striking motion wall tank walls that can damage the walls of the tank. Type 1 tank is a tank octagonal (octogonal) for membrane-type LNG carrier with dimensions of length $38 \mathrm{~m}$ width $39.17 \mathrm{~m}$ $14.5 \mathrm{~m}$ high side of the tank. Type 2 tank is a tank-shaped capsule with the long dimension of $26.6 \mathrm{~m}$ and a diameter of 10.5 m. Type 3 tank is rectangular tank (rectanguler) with dimensions of length of $49.68 \mathrm{~m}$, width 46.92 and $32.23 \mathrm{~m}$ high. Simulations conducted using Computational Fluid Dynamic (CFD) using ANSYS FLUENT software. From the simulation results concluded that the tank 1 to form (octogonal) have a total pressure of $3013.99 \mathrm{~Pa}$ on the front wall with a height of $13.65 \mathrm{~m}$ from the base of the tank
\end{abstract}

Keywords - fluent, heaving, pitching, sloshing, tank ship

\section{INTRODUCTION}

$\mathrm{T}$ ank is an important part of the central portion of

the vessel for transporting liquids or gases. Therefore designed a ship fluid carrier (oil tanker) and LNG carrier ships in a certain size to transport the fluid that loads can be distributed safely.

According to the relevant IMO on the LNG carrier, there are a wide variety of types of LNG tanks on ships. Are generally divided into two types of tanks that standalone tank is not integrated with the ship's construction (Independent Self Supporting Tank) and the tank are not stand-alone and integrated with the ship's construction (Non Self Supporting Tanks). The tank-type variation will affect the characteristics of fluid motion that is inside the tank [1].

As the main storage medium, the tank will always get a load of fluid taken and expenses that come from outside the tank. Sloshing is one burden that comes from inside the tank and sea waves is the burden that comes from outside the tank in which both the load can result in damage to the tank wall [9]. Hence the need for the simulation of sloshing and analysis of the structure of the tank due to the force created by the load. Sloshing the effect of the free movement of the fluid in the tank with the striking motion wall tank walls that can damage the walls of the tank [2].

In this research takes three types of LNG tanks with different shapes. The first tank is a tank type selfsupporting tank commonly called Self-supporting prismatic shape IMO type B (SPB tank). These tanks are designed to follow the shape of the hull (hull shape) that have a shape like a cube and discount simple

Edi Djatmiko, Department of Marine Engineering, Sepuluh Nopember Institute of Technology, Surabaya, 60111, Indonesia. Email: gusjadmiko@gmail.com

Yoga Adhi Pratama, Department of Marine Engineering, Sepuluh Nopember Institute of Technology, Surabaya, 60111, Indonesia. Email: yogaadhi2704@gmail.com construction similar to the construction of the tank tanker. The second is the type of tank bilobe type (Shaped like capsules) are installed separately (independent) of the hull and supported (supported) with steel cylinder (skirt). And the third is the type of membrane tank. Visually, this tank has a octogonal shape) and is a non-self-supporting tanks or tanks do not stand alone [3, 4].

Therefore, this study will analyze the characteristics of sloshing movement and direction of movement associated with the sloshing motion of the boat [10]. With the sloshing analysis showed that the walls of the tank which parts are experiencing the greatest potential damage when the pitching and heaving $[5,6]$.

\section{A. Problem Formulation}

Having regard to the subject matter that is contained in the background, then taken some formulation of the problem as follows:

1. How does the pitching and heaving motions against rectanguler shaped tank types, capsules and octogonal?

2. How is the pressure / force which occurs in three variations of the design of the tank with filling level $50 \%$ ?

3. How do the characteristics of fluid motion that is on the fluid in the tank three types?

\section{B. Objectives Thesis}

Based on the above background, the purpose and objective of this thesis is:

1. Modeling of three various types of tanks in CAD (Computational Adided Design) and CFD (Computational Fluid Dynamics)

2. Simulate sloshing against the three various types of filling the tank at the same level.

3. Knowing the movement of LNG and distribution of pressure caused by the movement of pitching and heaving with software CFD (Computational Fluid Dynamics) 


\section{Benefit}

The results of this research are expected to provide benefits to all parties associated with this research and especially the directly related parties, while the benefits of this thesis as follows:

1. Knowing the potential damage that would occur as a result of force / pressure on the walls of the tank.

2. Knowing the characteristics of the fluid due to movement of pitching and heaving

\section{Limitations}

The limits - limits in this research include:

1. Tank analyzed using three types of tanks with octogonal shape (type SPB), capsules (type bilobe) and form rectanguler (membrane type)

2. Analysis of fluid movement is done with the help of CAD modeling (Computational Aided Design) and (Computation Fluid Dynamic) without considering the construction and material tank

3. Analysis of pitching and heaving movements done with the help of CAD (Computational Aided Design)
4. Filling of liquid level in the tank is $50 \%$

5. Modeling fluid has material properties similar to Liquid Natural Gas

\section{METHOD}

\section{A. Data Collection}

Specification LNG Ship And Tank Data

In this research, ship data used as the modeling is the result of observation ship data that is so. However, for purposes of comparison are balanced then taken aboard one of the data contained in the background. In this thesis, the LNG carrier that will do the modeling is Disha LNG carrier ship which type of tank is a tank type membrane 96. Data obtained from general arrangement drawings and operating manuals cargo ship LNG carrier Disha which had previously been used in a thesis entitled "Simulation of sloshing about on Wall Type Membrane Tank LNG Ships Heaving and pitching movements result in Regular Waves"

TABLE 1

MAIN DIMENSION DATA LNG SHIP

\begin{tabular}{lcc}
\hline & Principle Dimention of LNG Ship \\
\hline LOA & 277 & $\mathrm{~m}$ \\
\hline LPP & 266 & $\mathrm{~m}$ \\
\hline LWL & 270.8 & $\mathrm{~m}$ \\
\hline B & 43.4 & $\mathrm{M}$ \\
\hline H & 26 & $\mathrm{M}$ \\
\hline T Design & 11.4 & $\mathrm{M}$ \\
\hline T Scantling & 12.5 & $\mathrm{M}$ \\
\hline Displacement & 100149 & Ton \\
\hline Deadweight & 70151 & Ton \\
\hline V Service & 19.5 & Knot \\
\hline
\end{tabular}

TABLE 2

DIMENSION DATA OF TANK 1

\begin{tabular}{ccccccc}
\hline $\begin{array}{c}\text { Membrane } \\
\text { Tank }\end{array}$ & $\begin{array}{c}\text { Dist } \\
\text { from } \\
\text { AP }(\mathrm{m})\end{array}$ & $\begin{array}{c}\text { Tank } \\
\text { Length } \\
(\mathrm{m})\end{array}$ & $\begin{array}{c}\text { Breadth } \\
\text { Moulded } \\
\text { Tank } \\
(\mathrm{m})\end{array}$ & $\begin{array}{c}\text { Breadth } \\
\text { Tank in } \\
\text { bottom } \\
(\mathrm{m})\end{array}$ & $\begin{array}{c}\text { Breadth } \\
\text { Tank on } \\
\text { top }(\mathrm{m})\end{array}$ & $\begin{array}{c}\text { Height } \\
\text { on side } \\
\text { tank }(\mathrm{m})\end{array}$ \\
\hline $\begin{array}{c}\text { No.1 Tank } \\
\text { Aft }\end{array}$ & 60.2 & & & & & \\
\hline $\begin{array}{c}\text { No.1 Tank } \\
\text { Fwd }\end{array}$ & 98.2 & 38 & 39.17 & 31.29 & 21.49 & 14.95 \\
\hline
\end{tabular}


International Journal of Marine Engineering Innovation and Research, Vol. 1(3), Jun. 2017. 175-188 (pISSN: 2541-5972, eISSN:2548-1479)

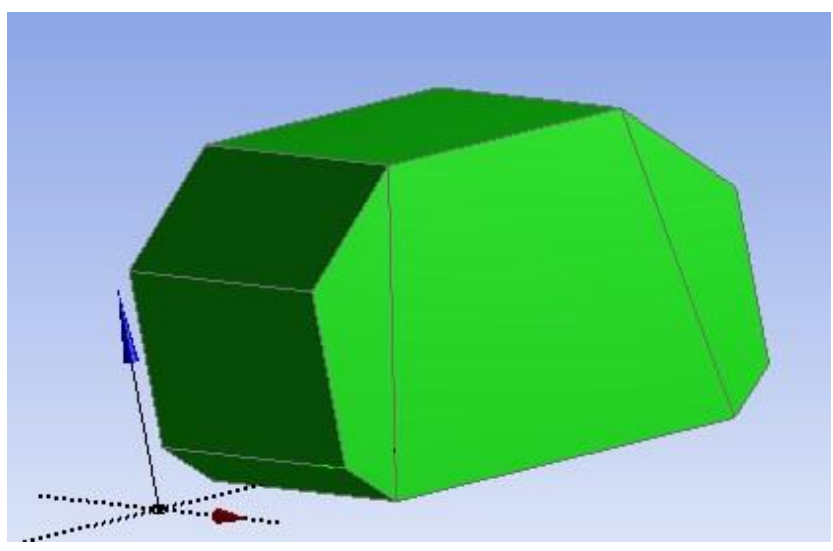

Figure. 1. Tank Design Variation 1

TABLE 3.

DIMENSION DATA OF TANK 2

\begin{tabular}{lcc}
\hline Lenght & 26.6 & $\mathrm{~m}$ \\
\hline Radius & 5.25 & $\mathrm{~m}$ \\
\hline Diameter & 10.5 & $\mathrm{~m}$ \\
\hline Material & Steel & \\
\hline
\end{tabular}



Figure. 2. Tank Design Variation 2

TABLE 4.

DIMENSION DATA OF TANK 3

AFT TANK No.4 (Inner Dimensions Given)

\begin{tabular}{lll}
\hline Tank aft from AP & 61.08 & $\mathrm{~m}$ \\
\hline Tank bottom from keel line & 3.3 & $\mathrm{~m}$ \\
\hline Tank length & 49.68 & $\mathrm{~m}$ \\
\hline Tank breadth & 46.92 & $\mathrm{~m}$ \\
\hline Tank height & 32.23 & $\mathrm{~m}$ \\
\hline
\end{tabular}




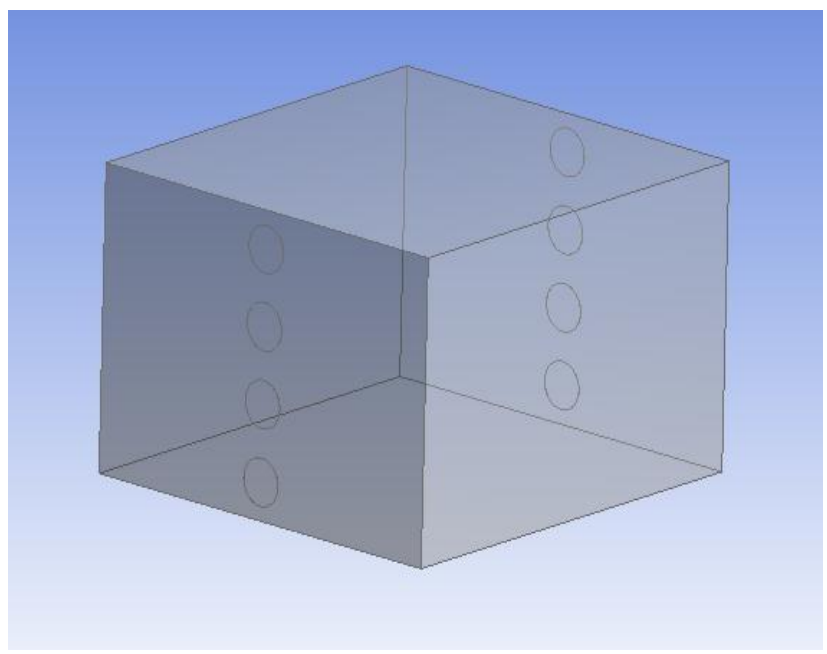

Figure. 3. Tank Design Variation 3

- LNG Ship Voyage Data

Wave data taken from a cruise ship LNG Disha is a cargo ship carrying LNG from race- Laffan (Qatar) to Dahej (India) so as to represent the territorial waters of the cruise ships environmental data is a region between India and Qatar. Thus, from the environmental data that has been mentioned, can be taken the data to be used as the calculation of the LNG vessel movements which are:

1. Wave period $(\mathrm{T})=10.2 \mathrm{~s}$

2. Wave Height $(\mathrm{H})=7 \mathrm{~m}$
3. The amplitude of the wave (a) $=3.5 \mathrm{~m}$

4. Sea water depth $(\mathrm{h})=1000 \mathrm{~m}$

\section{B. Data Collection}

- Calculation of Hydrostatic

Modeling the ship made with the help of software maxsurf dongle which in modeling within the software required ship hydrostatic calculation using an empirical formula with the final result of linesplan LNG Ships [7. $8]$.

TABLE 5

CALCULATION OF HYDROSTATIC

\begin{tabular}{|c|c|c|c|}
\hline Data & Formula & Source & Result \\
\hline $\mathrm{C}_{\mathrm{b}}$ & $\mathrm{Cb}=\Delta /$ L.B.T.p & Archimedes Law & 0.729 \\
\hline $\mathrm{C}_{\mathrm{m}}$ & $\mathrm{Cm}=1.006-0.0056 . \mathrm{Cb}^{-5.26}$ & Kerlen (1970) & 0.986 \\
\hline $\mathrm{C}_{\mathrm{p}}$ & $\mathrm{Cp}=\mathrm{Cb} / \mathrm{Cm}$ & Adrin Biran & 0,738 \\
\hline $\mathrm{C}_{\mathrm{wp}}$ & $\mathrm{Cwp}=(1+2 . \mathrm{Cb}) / 3$ & Schneekluth & 0.842 \\
\hline LCB & $\mathrm{Lcb}=(-0.135+0.195 \cdot \mathrm{Cp}) \cdot \mathrm{L}$ & Kerlen (1970) & 133.101 \\
\hline $\mathrm{KB}$ & $\mathrm{KB}=\mathrm{T} \cdot(0.9-0 \cdot 3 \cdot \mathrm{Cm}-0 \cdot 1 \cdot \mathrm{Cb})$ & Schneekluth & 6.047 \\
\hline WSA & $\mathrm{WSA}=1.7 . \mathrm{Lpp} \cdot \mathrm{T}+\nabla / \mathrm{T}$ & Denny & 152654.378 \\
\hline $\mathrm{A}_{\mathrm{BT}}$ & $\begin{array}{l}\mathrm{C}_{\mathrm{B}}\left(\mathrm{WSA}-\left(\mathrm{L}_{\pi \mathrm{T}} \cdot(2 \mathrm{~T}+\mathrm{B}) \sqrt{\mathrm{C} m} \cdot(0.452+\right.\right. \\
0.4425 . \mathrm{C}_{\mathrm{B}}-0.2862 . \mathrm{Cm} \cdot \\
\left.0.003467 . \mathrm{B} / \mathrm{T}-0.369 . \mathrm{C}_{\mathrm{m}}\right) / 2.36\end{array}$ & Holtrop and Mannen & 69.320 \\
\hline
\end{tabular}

\section{- Modeling Linesplan}

With hydrostatic data is already available, the ship modeling, manufacture linesplan and the tank can be done with the help of software maxsurf dongle. The goal is the size of the tank, which are located in the general arrangement precision movement of the ship can be searched with the help of software Seakeeper through linesplan that has been designed. After modeling with software obtained from the hydrostatic calculations maxsurf dongle software

\section{- Calculation of Ship Movement}

Perhitunggan movement to simulate the movement of the ship heaving and pitching. This calculation is done with the help of software Seakeeper. Data obtained from the data input environment cruise ship LNG. The input output obtained from pitching and heaving motions by the following equation:

The equation for the heaving motion

$\mathrm{Z}=-0,851 \cos .(0,67 . \mathrm{t})$

The equation for the pitching motion

$\theta=0.025 . \cos .(0,67 . t)$ 


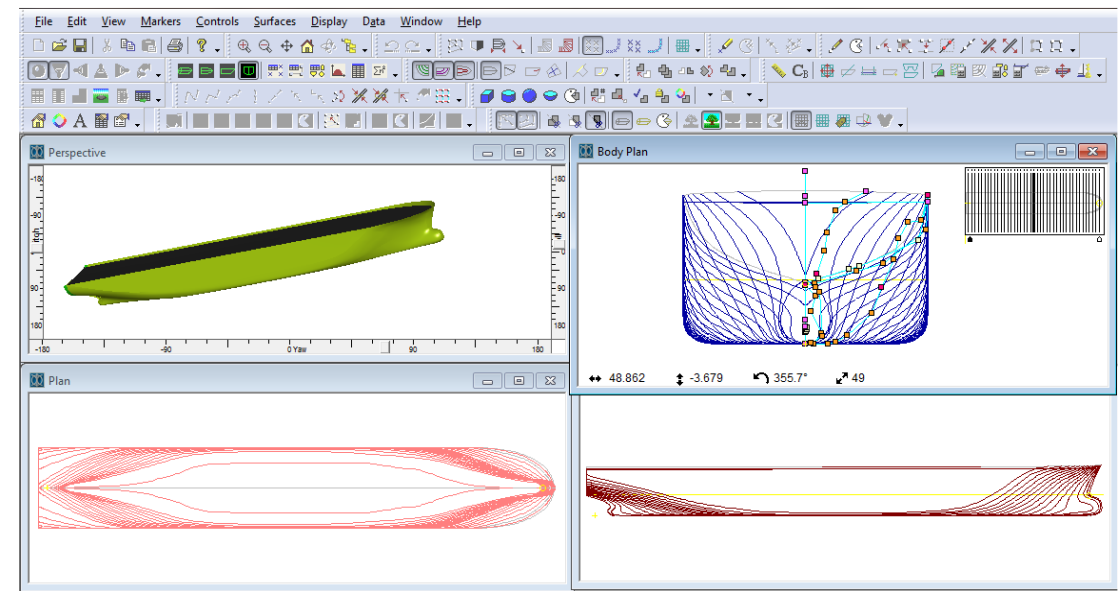

Figure. 4. Modeling Lines Plan

\begin{tabular}{|c|c|c|c|}
\hline & Measurement & Value & Units \\
\hline 1 & Displacement & 100433.866 & tonne \\
\hline 2 & Volume & 97984.259 & $m^{n} 3$ \\
\hline 3 & Draft to Baseline & 11.4 & $\mathrm{~m}$ \\
\hline 4 & Imrmersed depth & 11.4 & $\mathrm{~m}$ \\
\hline 5 & Lw' & 270.815 & $\mathrm{~m}$ \\
\hline 6 & Beam wl & 43.4 & $\mathrm{~m}$ \\
\hline 7 & MSA & 14434.133 & $m^{n} 2$ \\
\hline 8 & Max cross sect area & 483.57 & $m^{m} 2$ \\
\hline 9 & Waterplane area & 9920.68 & $m^{m} 2$ \\
\hline 10 & $C p$ & 0.748 & \\
\hline 11 & $\mathrm{Cb}$ & 0.731 & \\
\hline 12 & $\mathrm{Cm}$ & 0.978 & \\
\hline 13 & Cwp & 0.844 & \\
\hline
\end{tabular}

\begin{tabular}{|c|c|c|c|}
\hline \begin{tabular}{|l|}
14 \\
\end{tabular} & LCB from zero pt. ( $+\mathrm{v}$ & 133.918 & $\mathrm{~m}$ \\
\hline 15 & LCF from zero pt. (+v & 127.12 & $\mathrm{~m}$ \\
\hline 16 & LCB from zero pt. ( $+\mathrm{v}$ & 49.45 & $\%$ \\
\hline 17 & LCF from zero pt. $(+\mathrm{v}$ & 46.94 & $\%$ \\
\hline 18 & KB & 6.061 & $\mathrm{~m}$ \\
\hline 19 & $K G$ & 0 & $\mathrm{~m}$ \\
\hline 20 & BMt & 13.982 & $\mathrm{~m}$ \\
\hline 21 & EMI & 465.763 & $\mathrm{~m}$ \\
\hline 22 & GMt & 20.042 & $\mathrm{~m}$ \\
\hline 23 & GMI & 471.824 & m \\
\hline 24 & KMHt & 20.042 & $\mathrm{~m}$ \\
\hline 25 & KMI & 471.824 & $\mathrm{~m}$ \\
\hline 26 & Inmersion $(\mathrm{TPC})$ & 101.687 & tonne/c \\
\hline 27 & MTc & 1781.469 & tonne. $m$ \\
\hline 28 & RM at 1 deg $=$ GMt.Dis & 35130.485 & tonne.m \\
\hline 29 & Precision & Medium & 50 stati \\
\hline & (y) 1.025 tonne/min & & Recalc \\
\hline
\end{tabular}

Figure. 5. Hydrostatic Calculation Results with Software

- Use of User Defined Function (UDF)

User defined required in this thesis is the determination of pitching and heaving motions couple as well as the properties of LNG in the tank. Whereas in defining the movement of the tank, so that the movement speed is required, pitching and heaving motion equation has been obtained revealed to be the speed of movement experienced tank in the ship.
Heaving motion equation

$\mathrm{Z}=-0,851 \cos .(0,67 . \mathrm{t})$

$\mathrm{dZ} / \mathrm{dt}=-0.851 \times 0.67 \sin (0.67 . \mathrm{t})=0,57 \sin (0,67 . \mathrm{t})$

Pitching motion equation

$\theta=0,025 . \cos .(0,67 . t)$

$\mathrm{d} \theta / \mathrm{dt}=-0,025 \times 0,67 \cdot \sin (0 \cdot 67 \cdot \mathrm{t})=-0.017 \cdot \sin (0,67 . \mathrm{t})$ 


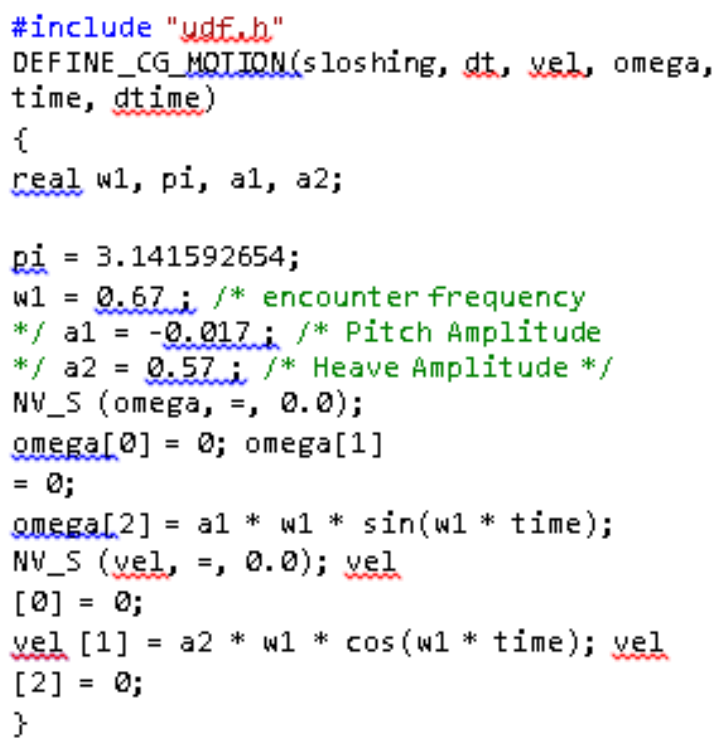

Figure. 6. programming language for defining wave motion on ANSYS fluent

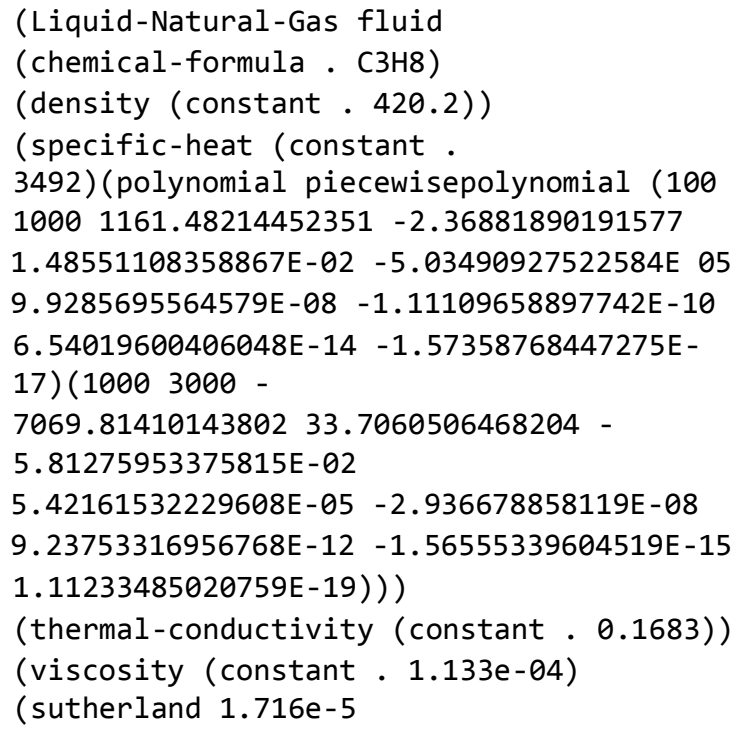

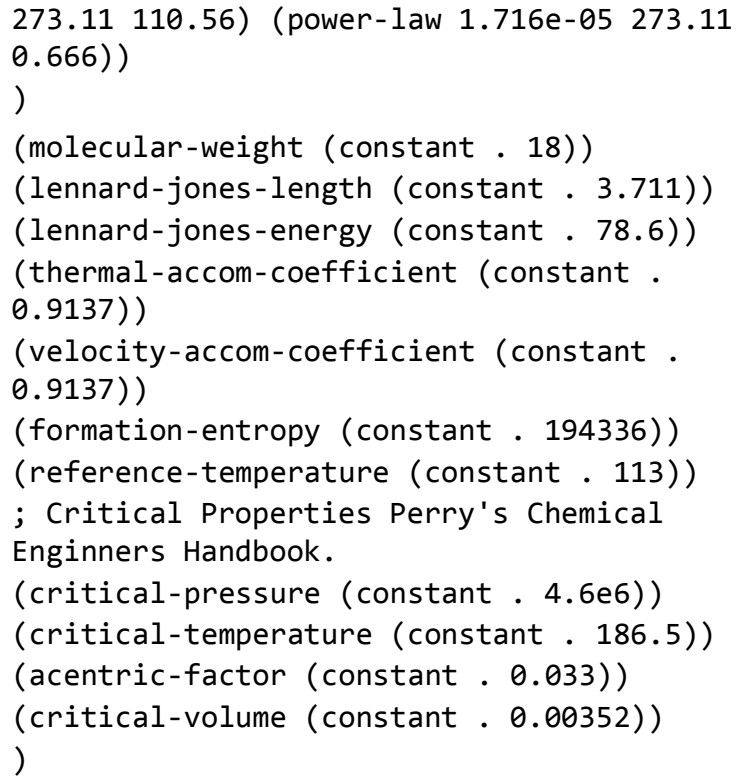

Figure. 7. programming language for define the fluid properties in this thesis, namely LNG

\section{RESULTS AND DISCUSSION}

\section{A. Node Determination Pressure on the tank}

\section{Node pressure is the point to determine where the total} pressure that occurs in each tank. Therefore, it was determined point on the front and back of the tank evenly. In each - each tank is determined five node points of pressure on the front and a five-point rear


Figure. 8. Node Pressure Position in Tank 1 
International Journal of Marine Engineering Innovation and Research, Vol. 1(3), Jun. 2017. 175-188 (pISSN: 2541-5972, eISSN:2548-1479)

TABLE 6.

NODE PRESSURE POTITION IN TANK 1

\begin{tabular}{cccc}
\multicolumn{2}{l}{ Aft Wall } & \multicolumn{2}{l}{ Fore Wall } \\
\hline $\mathrm{Z} 1$ & $22.75 \mathrm{~m}$ & $\mathrm{Z} 6$ & $22.75 \mathrm{~m}$ \\
\hline $\mathrm{Z} 2$ & $18.20 \mathrm{~m}$ & $\mathrm{Z} 7$ & $18.20 \mathrm{~m}$ \\
\hline $\mathrm{Z3}$ & $13.65 \mathrm{~m}$ & $\mathrm{Z} 8$ & $13.65 \mathrm{~m}$ \\
\hline $\mathrm{Z} 4$ & $9.10 \mathrm{~m}$ & $\mathrm{Z} 9$ & $9.10 \mathrm{~m}$ \\
\hline $\mathrm{Z} 5$ & $4.55 \mathrm{~m}$ & $\mathrm{Z} 10$ & $4.55 \mathrm{~m}$ \\
\hline
\end{tabular}

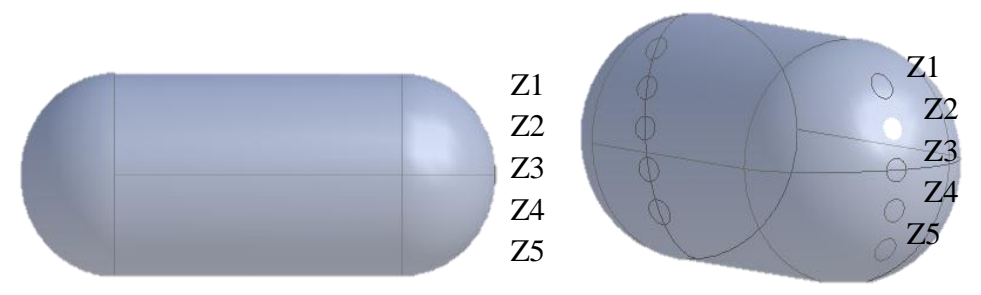

Figure. 9. Node Pressure Potition In Tank 2

TABLE 7.

NODE PRESSURE POTITION IN TANK 2

\begin{tabular}{lclc}
\hline \multicolumn{2}{c}{ Aft Wall } & \multicolumn{2}{c}{ Fore Wall } \\
\hline $\mathrm{Z} 1$ & $8.76 \mathrm{~m}$ & $\mathrm{Z} 6$ & $8.76 \mathrm{~m}$ \\
\hline $\mathrm{Z} 2$ & $6.99 \mathrm{~m}$ & $\mathrm{Z} 7$ & $6.99 \mathrm{~m}$ \\
\hline $\mathrm{Z} 3$ & $5.24 \mathrm{~m}$ & $\mathrm{Z} 8$ & $5.24 \mathrm{~m}$ \\
\hline $\mathrm{Z} 4$ & $3.49 \mathrm{~m}$ & $\mathrm{Z} 9$ & $3.49 \mathrm{~m}$ \\
\hline $\mathrm{Z} 5$ & $1.72 \mathrm{~m}$ & $\mathrm{Z} 10$ & $1.72 \mathrm{~m}$ \\
\hline
\end{tabular}
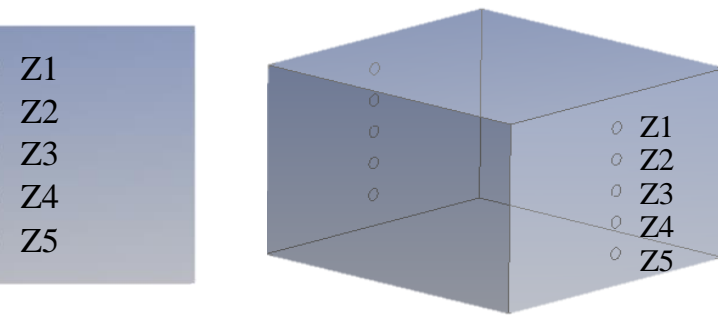

Figure. 10. Node Pressure Potition In Tank 3 
TABLE 8.

NODE PRESSURE POTITION IN TANK 3

\begin{tabular}{cccc}
\hline \multicolumn{2}{c}{ Aft Wall } & \multicolumn{2}{c}{ Fore Wall } \\
\hline $\mathrm{Z} 1$ & $26.85 \mathrm{~m}$ & $\mathrm{Z} 6$ & $26.85 \mathrm{~m}$ \\
\hline $\mathrm{Z} 2$ & $21.48 \mathrm{~m}$ & $\mathrm{Z} 7$ & $21.48 \mathrm{~m}$ \\
\hline $\mathrm{Z} 3$ & $16.11 \mathrm{~m}$ & $\mathrm{Z} 8$ & $16.11 \mathrm{~m}$ \\
\hline $\mathrm{Z} 4$ & $10.74 \mathrm{~m}$ & $\mathrm{Z} 9$ & $10.74 \mathrm{~m}$ \\
\hline $\mathrm{Z} 5$ & $5.37 \mathrm{~m}$ & $\mathrm{Z} 10$ & $5.37 \mathrm{~m}$ \\
\hline
\end{tabular}

\section{B. Simulation Results Tank 1 Type membrane}

\section{- Characteristics of Fluid Movement On Tank 1}

From the simulation results there are differences in fluid motions in the three tanks. Seen from the chart below the total pressure and velocity that occurs in the first tank walls are as follows:
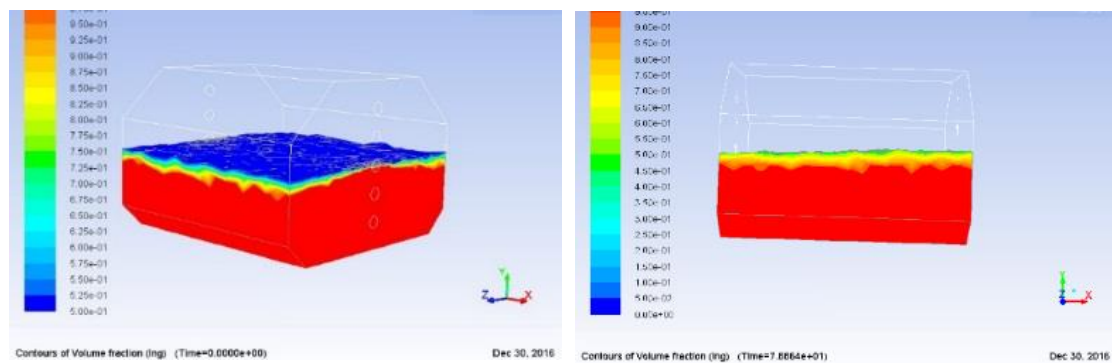

Figure. 11. Contour Tank Volume 1

The simulation results by the time calculation for 3000 time steps to show how the movement of the fluid and the total pressure on the walls of the tank as follows The front wall at $\mathrm{z} 3$ (13.65 $\mathrm{m}$ from the tank bottom) shows the total pressure at a maximum of $3013.99 \mathrm{kPa}$ and a total pressure by an average of $1216.47 \mathrm{kPa}$, on z4 (9:10 am from the tank bottom) shows the total amounting to $21685.34 \mathrm{kPa}$ maximum pressure and total pressure by an average of $19456.92 \mathrm{kPa}$.
The rear wall of the $\mathrm{z} 8$ ( $13.65 \mathrm{~m}$ from the tank bottom) shows the total pressure up to $920.49 \mathrm{kPa}$ and the total pressure by an average of $24.83 \mathrm{kPa}$, the $\mathrm{z} 9$ (9:10 am from the tank bottom) shows the total pressure at a maximum of $19084.64 \mathrm{kPa}$ and total pressure by an average of $17123.30 \mathrm{kPa}$.

From the graph it can be seen the movement of pressure on the front and rear walls average does not look stable pressure increase and decrease suddenly.

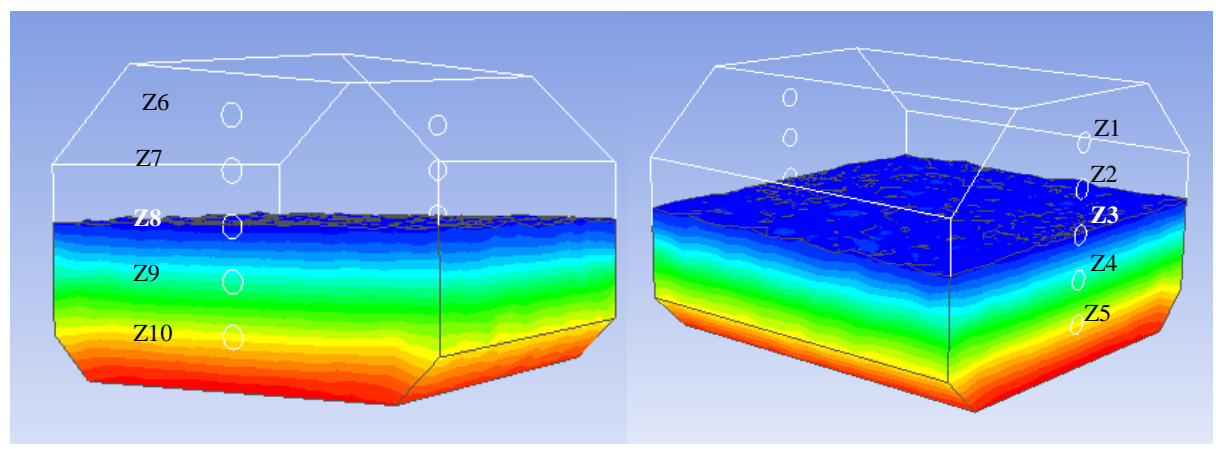

Figure. 12. Contour Pressure Tank 1 
TABLE 9.

THE TOTAL VALUE OF THE MAXIMUM PRESSURE IN THE TANK 2

Tank 1

\begin{tabular}{cccc}
\hline \multicolumn{2}{c}{ Aft Wall } & \multicolumn{2}{l}{ Fore Wall } \\
\hline Loc. $(\mathbf{m})$ & Pressure (kPa) & Loc. $(\mathbf{m})$ & Pressure (kPa) \\
\hline $\mathbf{2 2 . 7 5}$ & 0 & 22.75 & 0 \\
\hline $\mathbf{1 8 . 2 0}$ & 0 & 18.20 & 0 \\
\hline $\mathbf{1 3 . 6 5}$ & 3013.99 & 13.65 & 920.49 \\
\hline $\mathbf{9 . 1 0}$ & 21685.24 & 9.10 & 19084.84 \\
\hline $\mathbf{4 . 5 5}$ & 40750.67 & 4.55 & 38173.32 \\
\hline
\end{tabular}
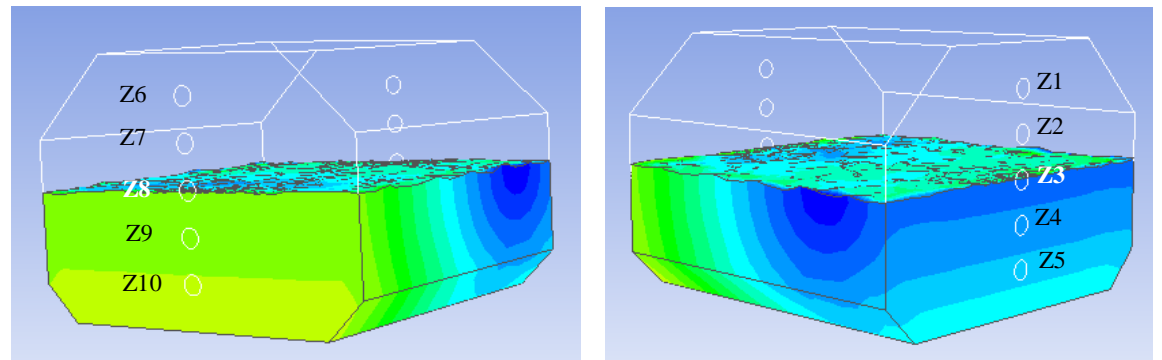

Figure. 13. Contour velocity magnitude on the walls of the tank 2

TABLE 10.

VALUE VELOCITY MAXIMUM MAGNITUDE AT FRONT AND REAR WALLS

Tank 1

\begin{tabular}{cccc}
\hline \multicolumn{2}{c}{ Aft Wall } & \multicolumn{2}{c}{ Fore Wall } \\
\hline Loc. $(\mathbf{m})$ & $\begin{array}{c}\text { Lelocity Magnitude } \\
(\mathbf{m} / \mathbf{s})\end{array}$ & $\begin{array}{c}\text { Velocity } \mathbf{~ M a g n i t u d e ~} \\
(\mathbf{m} / \mathbf{s})\end{array}$ \\
\hline $\mathbf{2 2 . 7 5}$ & 0 & 22.75 & 0 \\
\hline $\mathbf{1 8 . 2 0}$ & 0 & 18.20 & 0 \\
\hline $\mathbf{1 3 . 6 5}$ & 0.44 & 13.65 & 0.44 \\
\hline $\mathbf{9 . 1 0}$ & 0.44 & 9.10 & 0.44 \\
\hline $\mathbf{4 . 5 5}$ & 0.44 & 4.55 & 0.44 \\
\hline
\end{tabular}

The simulation results by the time calculation for 3000 time steps to show how the movement of the fluid and the total pressure on the walls of the tank as follows The front wall at $\mathrm{z} 3$ (13.65 $\mathrm{m}$ from the tank bottom) shows the total pressure at a maximum of $3013.99 \mathrm{kPa}$ and a total pressure by an average of $1216.47 \mathrm{kPa}$, on z4 (9:10 am from the tank bottom) shows the total amounting to $21685.34 \mathrm{kPa}$ maximum pressure and total pressure by an average of $19456.92 \mathrm{kPa}$.

The rear wall of the $\mathrm{z} 8(13.65 \mathrm{~m}$ from the tank bottom) shows the total pressure up to $920.49 \mathrm{kPa}$ and the total pressure by an average of $24.83 \mathrm{kPa}$, the $\mathrm{z} 9$ (9:10 am from the tank bottom) shows the total pressure at a maximum of $19084.64 \mathrm{kPa}$ and total pressure by an average of $17123.30 \mathrm{kPa}$.
To show the velocity in the tank wall is the front wall at z3 (13.65 $\mathrm{m}$ from the tank bottom) shows a maximum speed of $0439 \mathrm{~m} / \mathrm{s}$, the Z4 (9:10 am from the tank bottom) shows a maximum speed of $0439 \mathrm{~m} / \mathrm{s}$

The rear wall of the $\mathrm{z} 8(13.65 \mathrm{~m}$ from the tank bottom) shows the maximum speed of $0.438 \mathrm{~m} / \mathrm{s}$, the z9 (9:10 am from the tank bottom) shows a maximum speed of $0439 \mathrm{~m} / \mathrm{s}$.

From the graph it can be seen the movement of the fluid and the total pressure and the front and rear walls average does not look stable pressure increase and decrease suddenly. 
International Journal of Marine Engineering Innovation and Research, Vol. 1(3), Jun. 2017. 175-188 (pISSN: 2541-5972, eISSN: 2548-1479)

C. Simulation Results Tank 2 Type Bilobe

- $\quad$ Characteristics of Fluid Movement On Tank 2
From the simulation results seen from the graph below generate total pressure and velocity that occurs in the first tank walls are as follows:

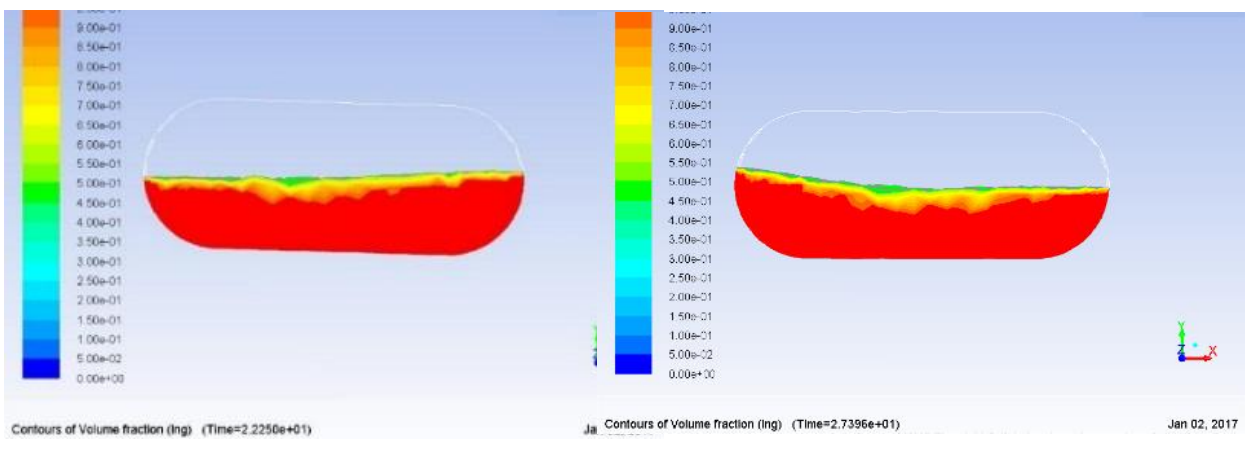

Figure. 14. Contour Fluid Tank Volume 2
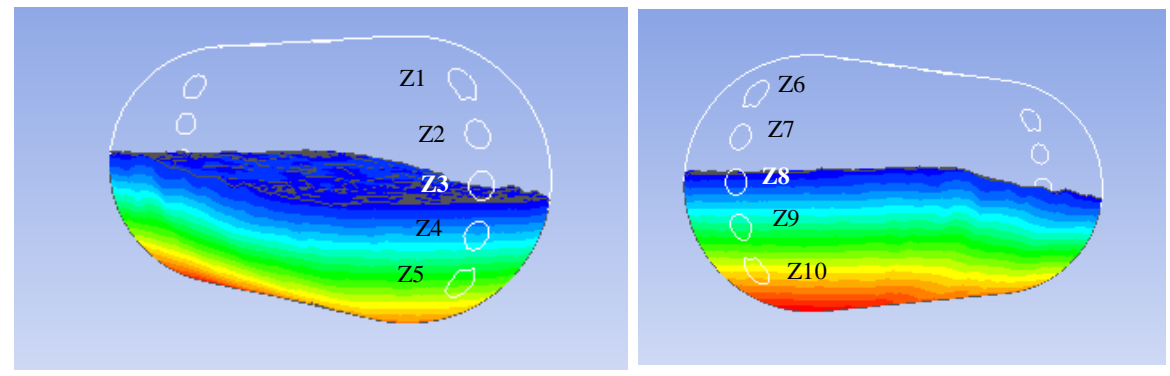

Figure. 15. Contour total pressure in the tank wall 2

TABLE 11.

THE TOTAL VALUE OF THE MAXIMUM PRESSURE ON THE FRONT AND REAR WALLS

Tank 2

\begin{tabular}{cccc}
\hline \multicolumn{2}{c}{ Aft Wall } & \multicolumn{2}{c}{ Fore Wall } \\
\hline Loc. $(\mathbf{m})$ & Pressure $(\mathbf{k P a})$ & Loc. $(\mathbf{m})$ & Pressure $(\mathbf{k P a})$ \\
\hline 8.76 & 0 & 8.76 & 0 \\
\hline 6.99 & 0 & 6.99 & 0 \\
\hline 5.24 & 5259.71 & 5.24 & 4185.66 \\
\hline 3.49 & 11790.46 & 3.49 & 10587.99 \\
\hline 1.72 & 18400 & 1.72 & 17176.11 \\
\hline
\end{tabular}
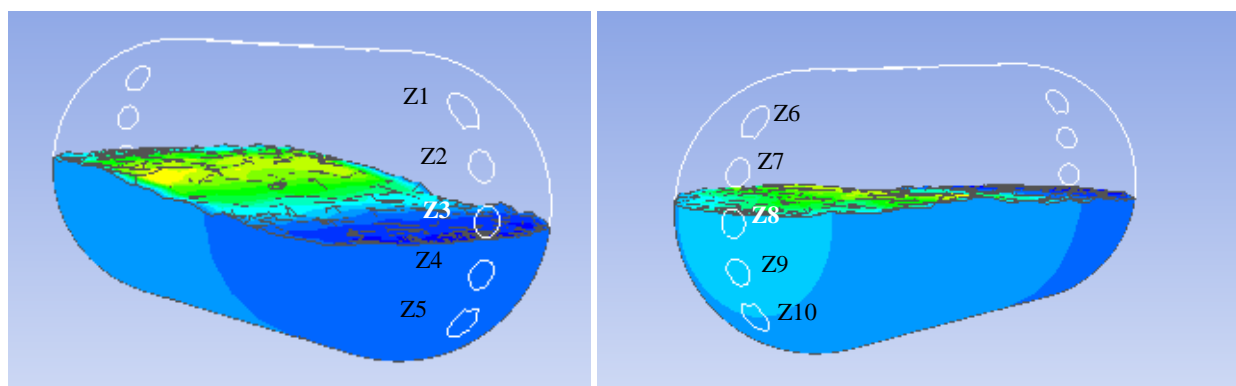

Figure. 16. Contour velocity magnitude on the tank 2 
TABLE 12.

VALUE MAXIMAL VELOCITY MAGNITUDE AT FRONT AND REAR WALLS

\begin{tabular}{cccc}
\hline & \multicolumn{2}{c}{ Tank 2 } & \\
\hline & Aft Wall & \multicolumn{2}{c}{ Fore Wall } \\
\hline Loc. $(\mathbf{m})$ & $\begin{array}{c}\text { Velocity Magnitude } \\
(\mathbf{m} / \mathbf{s})\end{array}$ & Loc. $(\mathbf{m})$ & $\begin{array}{c}\text { Velocity Magnitude } \\
(\mathbf{m} / \mathbf{s})\end{array}$ \\
\hline 8.76 & 0 & 8.76 & 0 \\
\hline 6.99 & 0 & 6.99 & 0 \\
\hline 5.24 & $0.41 \mathrm{~m} / \mathrm{s}$ & 5.24 & $0.41 \mathrm{~m} / \mathrm{s}$ \\
\hline 3.49 & $0.41 \mathrm{~m} / \mathrm{s}$ & 3.49 & $0.41 \mathrm{~m} / \mathrm{s}$ \\
\hline 1.72 & $0.41 \mathrm{~m} / \mathrm{s}$ & 1.72 & $0.41 \mathrm{~m} / \mathrm{s}$ \\
\hline
\end{tabular}

Data simulation with a time calculation 3000 time step to show the total pressure on the walls of the tank 2 is on the front wall at $\mathrm{z} 3$ (5:24 am from the tank bottom) shows the total pressure at a maximum of $5259,714 \mathrm{kPa}$, on $\mathrm{z} 4$ (3:49 am from the tank bottom) shows the total pressure maximum amounting to $11790.46 \mathrm{kPa}$. The rear wall of the $\mathrm{z} 8(5: 24$ am from the tank bottom) shows a total of $4185.66 \mathrm{kPa}$ maximum pressure, the $\mathrm{z} 9$ (3:49 am from the tank bottom) shows the total maximum pressure of $10587.99 \mathrm{kPa}$. In the graph velocity showed the front wall of the $\mathrm{z} 3$ (5:23 am on the bottom of the tank) a maximum speed of $0439 \mathrm{~m} / \mathrm{s}$, the Z4 (3:49 am from the tank bottom) shows a maximum speed of $0439 \mathrm{~m} / \mathrm{s}$ The rear wall of the $\mathrm{z} 8$ (5:23 am from basic tank) shows a maximum speed of $0.438 \mathrm{~m} /$ $\mathrm{s}$, the $\mathrm{z} 9$ (3:49 am from the tank bottom) shows the total pressure at a maximum of $0439 \mathrm{~m} / \mathrm{s}$.

\section{Simulation Results Tank 3 Type SPB}

- Characteristics of Fluid Movement On Tank 1 From the simulation results seen from the graph below generate total pressure and velocity that Occurs in the first tank walls are as follows:

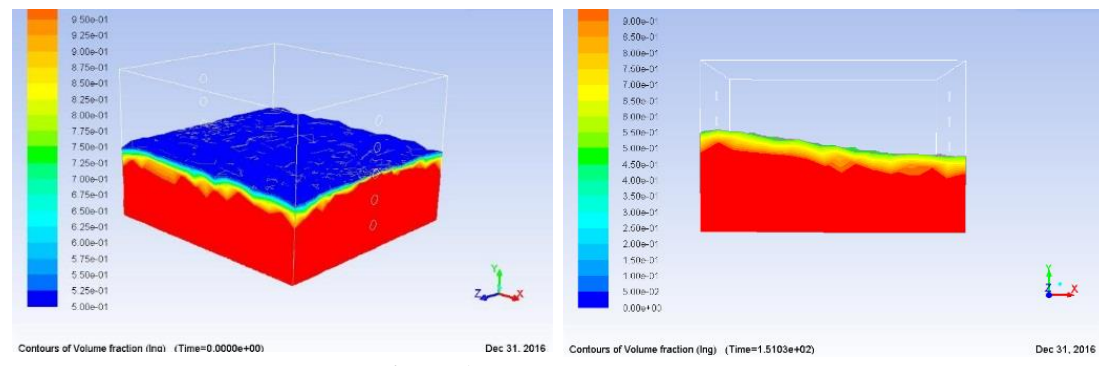

Figure 17. Contour of volume fraction

Data simulation with a time step calculations for 3000 show the total pressure on the walls of the tank are as follows. The front wall at z3 (16:11 m from the tank bottom) shows the total pressure at a maximum of $12585.41 \mathrm{kPa}$ and total pressure by an average of $1646.39 \mathrm{kPa}$, on $\mathrm{z} 4$ (10.74 $\mathrm{m}$ from the tank bottom) shows the total pressure at a maximum of $32434.84 \mathrm{kPa}$ and total pressure average - average amounting to $22045.27 \mathrm{kPa}$,
The rear wall of the $\mathrm{z} 8(16: 11 \mathrm{~m}$ from the tank bottom) shows the total pressure up to $9556.34 \mathrm{kPa}$ and a total pressure by an average of $486.13 \mathrm{kPa}$, the $\mathrm{z} 9$ ( $10.74 \mathrm{~m}$ from the tank bottom) shows the total pressure at a maximum of $28897.48 \mathrm{kPa}$ and total pressure by an average of $19453.37 \mathrm{kPa}$.

In the graph indicates pressure constant motion but an increase in pressure on the front wall and rear wall of the tank, the longer it is used to calculate the greater the pressure given on the tank wall.
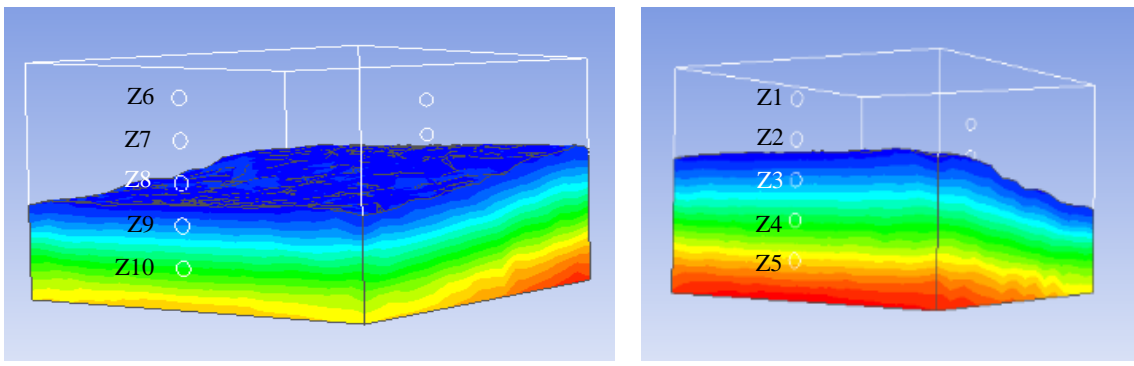

Figure. 18. Contour total pressure in the tank 3 
TABLE 13.

VALUE MAXIMUM PRESSURE ON THE FRONT AND REAR WALLS

Tank 3

\begin{tabular}{cccc}
\hline \multicolumn{2}{l}{ Aft Wall } & \multicolumn{2}{c}{ Fore Wall } \\
\hline Loc. $(\mathbf{m})$ & Pressure (kPa) & Loc. $(\mathbf{m})$ & Pressure $(\mathbf{k P a})$ \\
\hline 26.85 & 0 & 26.85 & 0 \\
\hline 21.48 & 0 & 21.48 & 0 \\
\hline 16.11 & 12585.41 & 16.11 & 9556.34 \\
\hline 10.74 & 32434.84 & 10.74 & 28897.48 \\
\hline 5.37 & 53547.02 & 5.37 & 49436.56 \\
\hline
\end{tabular}

Simulation data to show the velocity on the walls of the tank as follows:

The front wall at $\mathrm{z} 3$ (16:11 $\mathrm{m}$ from the tank bottom) shows a maximum speed of $0.475 \mathrm{~m} / \mathrm{s}$, the Z5 (5:37 am from the tank bottom) shows the total pressure at a maximum of $0480 \mathrm{~m} / \mathrm{s}$

The rear wall of the $\mathrm{z} 8(16: 11 \mathrm{~m}$ from the tank bottom) shows the maximum speed of $0.475 \mathrm{~m} / \mathrm{s}$, the z10 (5:37 am from the tank bottom) shows the total pressure at a maximum of $0.482 \mathrm{~m} / \mathrm{s}$

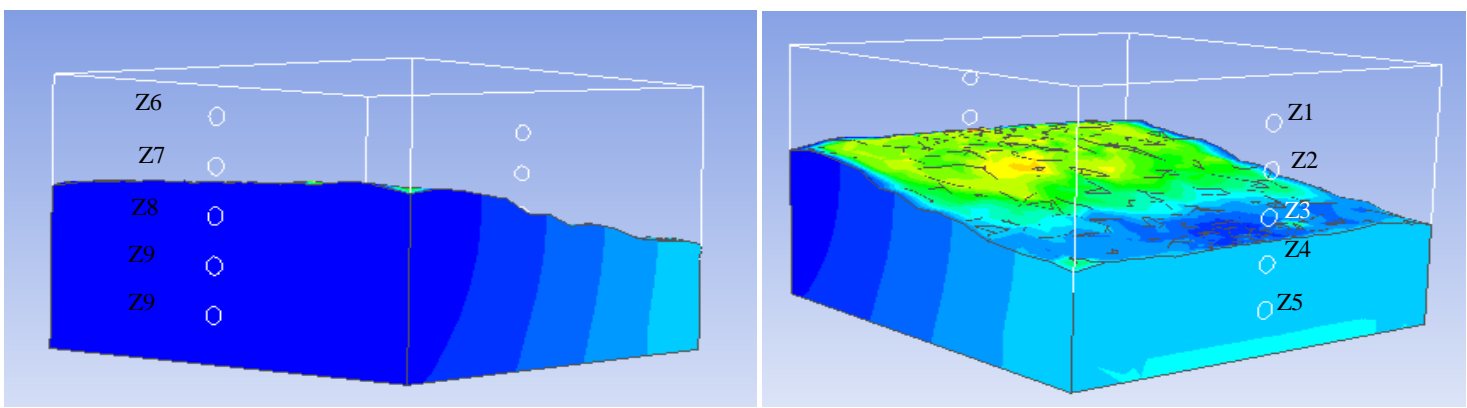

Figure. 19. Contour velocity magnitude in the tank 3

TABLE 14 VALUE MAXIMAL VELOCITY MAGNITUDE AT FRONT AND REAR WALLS

Tank 3

\begin{tabular}{cccc}
\hline & Aft Wall & \multicolumn{2}{c}{ Fore Wall } \\
\hline Loc. $(\mathbf{m})$ & $\begin{array}{c}\text { Velocity Magnitude } \\
(\mathbf{m} / \mathbf{s})\end{array}$ & $\begin{array}{c}\text { Loc. } \\
(\mathbf{m})\end{array}$ & $\begin{array}{c}\text { Velocity Magnitude } \\
(\mathbf{m} / \mathbf{s})\end{array}$ \\
\hline 26.85 & 0 & 26.85 & 0 \\
\hline 21.48 & 0 & 21.48 & 0 \\
\hline 16.11 & $0.48 \mathrm{~m} / \mathrm{s}$ & 16.11 & $0.48 \mathrm{~m} / \mathrm{s}$ \\
\hline 10.74 & $0.48 \mathrm{~m} / \mathrm{s}$ & 10.74 & $0.48 \mathrm{~m} / \mathrm{s}$ \\
\hline 5.37 & $0.48 \mathrm{~m} / \mathrm{s}$ & 5.37 & $0.48 \mathrm{~m} / \mathrm{s}$ \\
\hline
\end{tabular}

\section{CONCLUSION}

\section{A. Conclusion}

From the analysis of the three variations of the model octogonal shaped tank (membrane type) (a), capsule- shaped tank (type bilobe) (b) and rectangular shaped tank (type SPB) (c) and the above discussion to answer the purpose of this thesis can be summarized: 

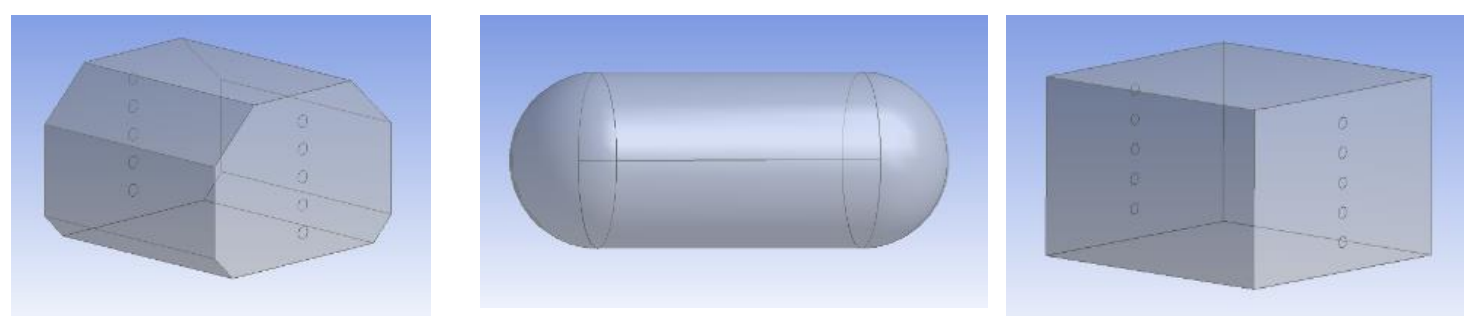

Figure. 20. Modeling tank with Aidded Computational Design (CAD
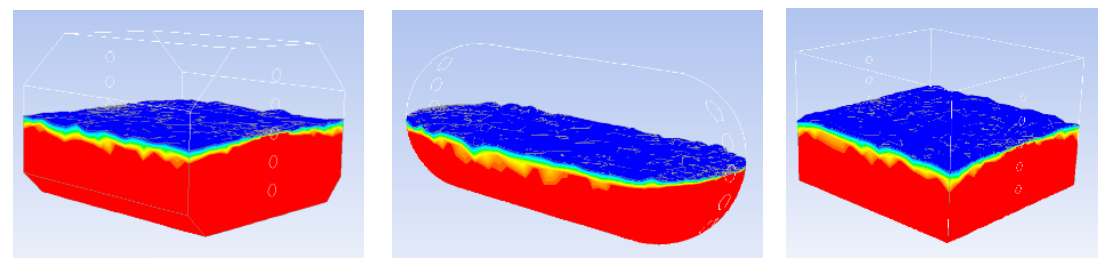

Figure. 21. Modeling tank with Computational Fluid Dynamic (CFD)
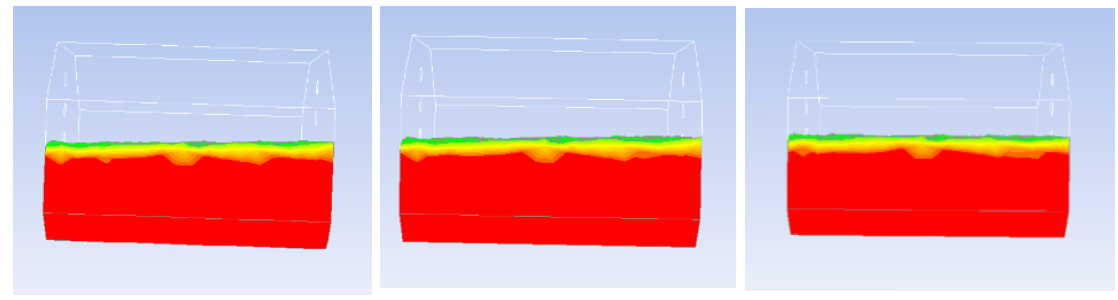

Figure. 22. The results of the simulation screenshots sloshing against the three types of tank 1
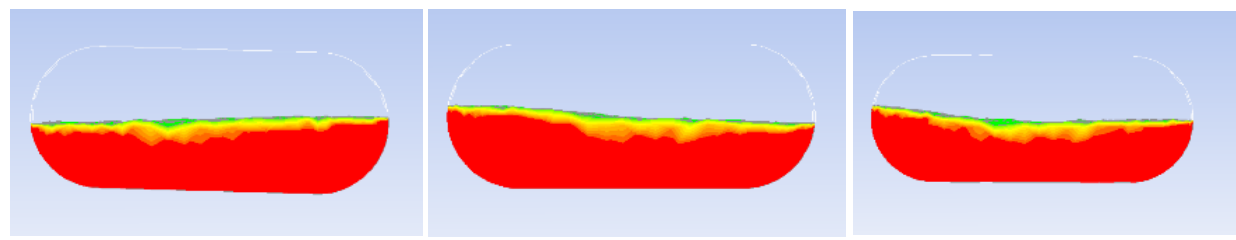

Figure. 23. The results of the simulation screenshots sloshing against the three types of tank 2
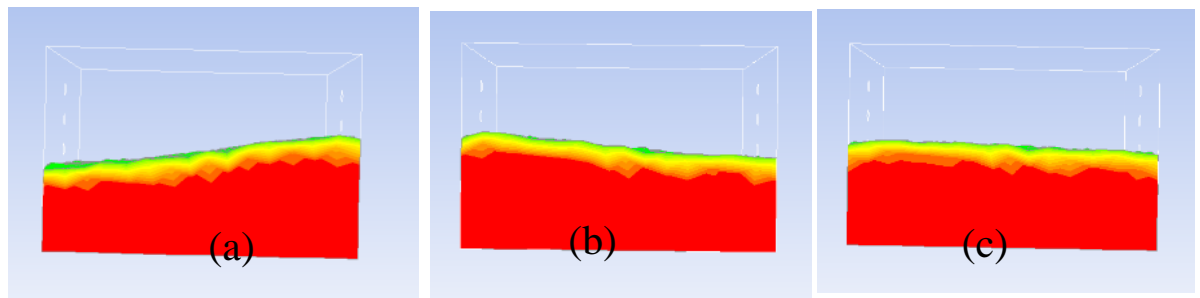

Figure. 24. The results of the simulation screenshots sloshing against the three types of tank 3

1. Based on the simulation results obtained three types of tank fluid motion in the tank Type 1 tank with octogonal shape (membrane type) discount total pressure on the front wall is greater than the total pressure on the back wall. No raising pressure suddenly walked constant fluid movement. The fluid velocity in the tank moving at a constant speed with an average speed of $0.3 \mathrm{~m} / \mathrm{s}$

2. Type 2 tank with a capsule form (Type Bilobe) discount total pressure on the front wall is greater than the total pressure on the rear wall seen from a maximum total pressure is given on the second wall tersebut.dan if observed from the graph, the simulation results seem to occur increased pressure. The movement of the fluid in the tank has a constant maximum speed that does not happen enhancement and reduction in speed is soaring.

3. Type 3 tank with rectanguler form (Type SPB) has the total pressure on the front wall is greater than the total pressure in the rear wall seen from the simulation results in the tank. Observed from the graph the total pressure applied to the wall it will increase pressure on the wall. The longer the calculation time is given, the total pressure will further increase. For speed of the fluid in the tank discount constant speed by an average of $0.3 \mathrm{~m} / \mathrm{s}$

\section{B. Suggestion}

Based on the analysis that has been done and could be concluded in writing, then it is given the following advice: 
1. Keep the variation filling the tank level and the location of other nodes to get more specific results

2. Need for comparison, variations and additions other than heaving and pitching motion so that fluid movement may be more in line with actual ship movements

3. Need for a comparative analysis between the experimental results and an analysis software to make more accurate

4. Keep the volume ratio equal to each tank

\section{REFERENCES}

[1] Anwar, M.S. (2013). Simulasi Sloshing pada Dinding Tangki Tipe Membran Kapal LNG Akibat Gerakan Heaving dan Pitching di Gelombang Regular (Final Project). Surabaya : Institut Teknologi Sepuluh Nopember.

[2] Fahlevi, Rizal (2014). Analisa Pengaruh Sloshing Pada Ruang Muat Kapal LNG Terhadap Stabilitas Kapal Dengan Pendekatan CFD” (Final Project). Surabaya: Institut Teknologi Sepuluh Nopember.

[3] Rifai, S.B. (2012). Analisa Sloshing Secara Memanjang Pada Tangki FLNG Dengan Menggunakan Metode Computational Fluid Dynamic CFD (Final Project). Surabaya: Institut Teknologi Sepuluh Nopember.

[4] Bhattacharrya, R. (1978). Dynamics Of Marine Vehicles. New York: Wiley Publication.

[5] Arsad, Ashar Khoirul (2013). Studi Gerakan Sloshing terhadap Tangki Kotak (Rectangular Tank) Dengan dan Tanpa Pelat Memanjang (Baffle) Akibat Gerakan Rolling Kapal Dengan Metode Computational Fluid Dynamics (CFD)” (Final Project). Surabaya: Institut Teknologi Sepuluh Nopember.

[6] Sloshing Assessment Guidance Document for Membrane Tank LNG Operations (2009). London; Llyod Register.

[7] Sugiarso, Adin. (2010). Maxsurf Training 2010 Basic Level.Surabaya

[8] Tautika, Firman. (2008). Dasar-Dasar CFD Menggunakan Fluent. Bandung: Informatika.

[9] A. Z. M. Fathallah and F. H. Husein, "Technical Analysis of Influence of Special Treatment on Water Ballast Treatment by using Active Carbon on Vessel and Environment," Int. J. Mar. Eng. Innov. Res., vol. 1, no. 1, Dec. 2016.

[10] H. Prastowo, D. P. Widodo, Semin, and W. Rohmawati, "Technical Analysis Ballast Water Treatment By Using Economizer Utilizing Main Engines Exhaust Heat To Comply With International Ship Ballast Water Management At Mv. Leader Win," Int. J. Mar. Eng. Innov. Res., vol. 1, no. 2, Mar. 2017. 